\title{
Tax Aggressive Behaviour in Private Family Firms - The Effect of the CEO and Board of Directors
}

\author{
Tensie Steijvers ${ }^{1}$, Mervi Niskanen ${ }^{2}$ \\ ${ }^{1}$ KIZOK Research Center, Faculty of Applied Economics at Hasselt University, Diepenbeek, Belgium \\ Research Foundation-Flanders (FWO), Brussels, Belgium \\ 2Department of Business, Faculty of Applied Economics, University of Eastern Finland, Kuopio, Finland \\ tensie.steijvers@uhasselt.be \\ mervi.niskanen@uef.fi
}

\begin{abstract}
Tax aggressiveness is defined as downward management of taxable income through tax planning activities which can be legal or illegal or may lie in between. Given that taxes are an important cost for each firm, tax aggressiveness may be desired by its shareholders. In this paper, we investigate to what extent CEO ownership and governance (e.g. composition of the board of directors) affect tax aggressive behavior decisions in private family firms. More specifically, we extend prior knowledge by studying how board's monitoring behavior may moderate the relationship between the CEO's involvement in the firm and tax aggressive behaviour of the firm. The data, collected through a private survey, consist of 600 Finnish family and non family SMEs and is a panel with observations from the years 2000-2005. The model is estimated based on robust Ordinary Least Squares estimations including several moderating effects. In this paper, we find that private family firms appear to be less tax aggressive than private non family firms. Even though tax aggressive behaviour provides tax savings and allows the CEO to mask rent extraction (e.g. earnings management, perquisite consumption, excessive salaries...) to the detriment of other shareholders, the non financial costs being the possible reputation damage and loss of socioemotional wealth seem to outweigh the benefits. Within the group of private family firms, results show that family firms with a lower CEO ownership share are more eager to engage in tax aggressive behaviour. This result highlights the importance of the unique agency conflict between the CEO (agent and possibly principal) and (other) shareholders (principals) in determining family firms' tax reporting. Finally, our results show that the presence of an outside director in the board of directors improves the monitoring effectiveness which reduces the tax aggressive behavior of those private family firms with low CEO ownership shares.
\end{abstract}

Key words: private family firms, tax aggressiveness, socioemotional wealth

\section{Introduction}

Tax aggressiveness is defined as downward management of taxable income through tax planning activities which can be legal or illegal or may lie in between (Frank et al., 2009). To what extent a firm is tax aggressive has to be chosen by the firm. As the CEO plays an economically significant role in determining the level of tax avoidance that firms undertake, the CEO can be considered as the decision maker (Dyreng et al., 2010). The CEO has to trade off the marginal benefits against the marginal costs of managing taxes.

Chen et al. (2010) indicate that our understanding of tax reporting aggressiveness is limited and even lacking in a context of private family firms. However, private family firms are particularly suitable to study tax aggressiveness. Desai and Dharmapala (2006) indicate that the analysis of a tax aggressiveness decision is embedded in an agency framework in which managers can enjoy private benefits of control at the expense of other shareholders. Given that private ownership lacks disciplining of the market for corporate control, agency costs could be high (Schulze et al., 2001).

For private family firms, the benefits do not only include the tax savings but tax aggressiveness also allows the CEO to mask any kind of rent extraction vis-à-vis the other shareholders (e.g. earnings management, perquisite consumption, excessive salaries ...). This rent extraction can be considered as agency costs for the firm. On the cost side, the CEO has to take into account the time that has to be invested to implement the tax evasion measures, the possible penalty from tax authorities and the possible damage to the firm's reputation and family's socioemotional wealth. Private family firms have a much longer investment horizon and greater reputation concerns (Gedajlovic and Carney, 2010). Family 
firms do not only have financial goals but also noneconomic goals such as preservation of the family dynasty and perpetuation of family values through the business, that meet the family's affective needs which is described as socioemotional wealth (Gomez-Mejia et al., 2007).

Therefore, the main objectives of this study is to determine whether from an agency perspective, private family firms, compared to private non family firms, are more or less eager to engage in tax aggressive behavior. Moreover, we question whether the extent of separation between ownership and management, affecting the extent of agency problems, will also affect tax aggressive behavior. Additionnally, we extend prior knowledge by studying how effective monitoring by a board of directors may mitigate the agency problems arising from separation between ownership and control, resulting in tax aggressive behavior.

\section{Literature review and hypothesis development}

According to traditional agency theory, privately family owned and managed firms are often considered as a low agency cost case (Jensen and Meckling, 1976; Fama and Jensen, 1983). Family members would be more likely to behave altruistically. Parental altruism is a utility function in which the welfare of parents is positively linked to the welfare of their children. Altruism may have several beneficial effects such as the creation of a self-reinforcing system of incentives encouraging family members to be considerate of one another (Schulze et al., 2003) and the enforcement of incentives to communicate and cooperate with each other. When a firm is owned solely by a single owner-manager, it can even be considered as a zero agency cost case (Ang et al., 2000).

However, by (partially) separating ownership from management in private family firms, agency costs may arise due to information asymmetries and strains on the limits of bounded rationality among family owners. The interests of owner(s) and manager(s) may not be completely aligned: the ability of the CEO to act in his own interests at the expense of (other) family firm owners will increase (Chua et al., 2003). Engaging in tax aggressive behavior by the CEO may be a reflection of this shareholder-manager agency problem.

Engaging in tax aggressive activities is accompanied by costs and benefits within the context of private family firms. As Dyreng et al. (2010) indicate that the CEO plays an economically significant role in determining the level of tax avoidance that firms undertake, we take the perspective of the CEO in studying the costs and benefits of tax aggressive behavior that determine the actual extent of tax aggressiveness.

Chen et al. (2010) provide an overview of these costs and benefits. On the benefit side, there are the direct tax savings which benefit all shareholders. Moreover, the complexity and obscure nature of tax aggressiveness may allow the CEO to mask or hide any kind of rent extraction activities (e.g. earnings management, perk consumptions, excessive compensation ...). On the cost side, the firm risks a potential penalty by the tax authorities. Moreover, if other shareholders perceive tax aggressive behaviour as a way to mask rent extraction, a price discount will be imposed on the firm's shares.

However, in private family firms, we argue that the costs are slightly different. First, contrary to public firms (Chen et al., 2010), this rent extraction and other perquisite consumption behaviour by the CEO (Schulze et al., 2003), will not be punished by the shareholders by a price discount because private ownership lacks disciplining of the market for corporate control. Moreover, the lack of external discipline increases the likelihood that information asymmetries will develop vis-à-vis for example outside shareholders (Lubatkin et al., 2005). Additionally, previous studies indicate that CEO turnover is significantly lower in family firms, indicating that possible rent extraction is less likely to be punished by the shareholders (Tsai et al., 2006). Secondly, since private family firm owners are underdiversified and have their wealth tied disproportionately to their firms, any penalty for the tax authorities is more likely to be substantial to them. Thirdly, there is the possible damage caused to their reputation in case of a tax related lawsuit, which seems to be most important to private family firms. Due to the large equity ownership by the family, private family firms have a much longer investment horizon and greater reputation concerns compared to public firms (Gedajlovic and Carney, 2010). They want to pass the firm 
onto the heirs and want to preserve the reputation of the family name. Family owners want to protect the family name as they view their firms as legacies to be handed over to the next generations. Family firms have been represented as a combination of an emotion-oriented family system focussing on non economic goals and the results-oriented business system focussing on economic goals. Non economic goals such as preservation of the family dynasty and perpetuation of family values through the business, that meet the family's affective needs are described as socioemotional wealth. Especially in private family firms, family wealth is closely linked with the socioemotional wealth the family obtains from controlling the firm (Gomez-Mejia et al., 2007). So, preserving the socioemotional wealth is itself a key goal in many private family firms.

Therefore, we argue that, in general, the reputation concerns and preservation of the socioemotional wealth, specific for private family firms, outweighs the benefits of tax aggressive behaviour in private family firms. So:

\section{Hypothesis 1: Private family firms exhibit a lower level of tax aggressive behaviour compared to private non-family firms.}

There is a growing consensus that private family firms cannot be viewed as a homogeneous entity (Westhead and Howorth, 2007). Specific family firm characteristics may influence the private family firm's agency problems and resulting tax aggressive behavior. Given the importance of the decision makermanager in this context (Dyreng et al., 2010), we take into account the CEO's ownership share.

If the CEO has a high ownership share, he bears many of the costs and receives nearly all of the benefits of any of his actions including tax aggressiveness. A CEO with a high ownership share is mainly worried by the preservation of the good reputation and passing the firm to his children. They may be less eager to engage in rent extraction because this may harm the firm. Parental altruism gives the controlling owner/CEO incentive to take actions that they believe would benefit the nuclear family. In addition, the emotional attachment to and self identification with the firm and the utility derived from the ability to exercise authority are strong (Gomez-Mejia et al., 2007). Therefore, the CEO will be less inclined to engage in tax aggressive activities because the avoidance of any penalty from the tax authorities, negative publicity or loss of socioemotional wealth are essential.

A CEO with a lower or no ownership share may be more inclined to engage in tax aggressive activities. The low CEO ownership share usually arises due to succession of the firm over several generations, which weakens the attachment of the family to the firm. The focus shifts from from family goals to a combination of family and business goals. Family ties and altruistic feelings weaken and the family CEO with low ownership share will often put the welfare of the own nuclear family before the wealth of the extended family (Karra et al., 2006; Lubatkin et al., 2005). This low ownership share may reduce the motivation of descendant CEO's, which increases the incentive to act opportunistically because they bear only part of the cost of such action. It may enhance rent extraction by the CEO. The shareholder-manager agency conflict becomes more prominent. The reputation effect of tax aggressive behavior and the incentive to preserve socioemotional wealth becomes of minor importance since the family ties have weakened and the intra family conflict may intensify.

If the CEO has no ownership share and is thus a professional outside CEO, ownership and management are completely separated which may lead to significant shareholder-manager agency costs due to misalignment of incentives. Goals of manager (agent) and owner(s) (principal) can diverge because the outside manager is not always familiar with the family goals or may choose other goals than those strived for by the family shareholders. He will have a more short term view compared to a family CEO. He will be evaluated based on the financial performance and the cost savings he achieves. So, he will be more inclined to improve the financial results for the family shareholders and engage in tax aggressive activities. Since family firms are not eager to provide outside managers with equity shares, they will be more likely to receive a performance based salary or bonus (Banghoy et al., 2010). Outside CEOs are expected to be less concerned with penalties from the tax authorities or other long term implications with 
regard to reputation or socioemotional wealth. They are brought in to provide objectivity and more rationality (Blumentritt et al., 2007). They do not strive at life time employment. Thus:

Hypothesis 2: Private family firms with a high CEO ownership stake exhibit a lower level of tax aggressive behavior

However, the board of directors may in several ways be an instrument to reduce shareholder-manager agency problems and restrict tax aggressive behaviour by the CEO. In private family firms, boards of directors may perform several board roles (Voordeckers et al., 2007). The board is responsible for monitoring and evaluating management. Within an effective corporate governance structure, the board verifies whether the management acts in the best interest of the shareholders. In case of sound corporate governance, the directors should detect any kind of rent extraction behavior and report it to the shareholders. To perform this task effectively, the directors should have the necessary expertise and objectivity that ostensibly mitigates the expropriation of firm resources for example by rent extraction. Therefore, as rent extraction possibilities are reduced, the incentive for a CEO to engage in tax aggressive behaviour to mask rent extraction would be reduced. As argued above, private family firms with a lower CEO ownership share would be more eager to engage in tax aggressive behavior. In those firms, the advantages of tax aggressiveness become dominant since the preservation of the firms reputation and socioemotional wealth are less important due to weaker family ties. However, the control role performed by an effective board reduces this tax aggressive behavior by avoiding rent extraction such as excessive CEO compensation and thereby reducing the motivation of the CEO to engage in tax aggressive activities. Moreover, in case of tax related law suits, the reputation of the board may also be threatened. It may subject the directors to heavy criticism. Therefore, they will try to reduce the extent of tax aggressive behavior.

Therefore, we consider the moderating effects of an effective board of directors on the relationship between CEO ownership and tax aggressiveness. So:

Hypothesis 3: The negative relationship between CEO ownership and tax aggressive behaviour will be weakened by effective monitoring by the board of directors

\section{Data and variables}

\subsection{Data set}

The data for the study were collected through a private survey. The database consists of 600 Finnish SMEs and is a panel with observations from the years 2000-2005. A private family firm is defined as a firm where more than $50 \%$ of the shares is owned by the family. This definition is in line with the majority of family business definitions that require family ownership as one of the main indicators for defining a family firm (Chua et al., 1999). The model will be estimated based on robust OLS estimations including several moderating effects. After elimination of outliers we ended up with a final sample of 1621 private family and non family firms out of which 921 firms are categorized as 'family firms'.

\subsection{Measures}

The dependent variable we use is the effective tax rate defined as total tax expense divided by earnings before taxes. Firms that are more aggressive have lower effective tax rates (ETRs). This measure reflects aggressive tax planning through permanent book-tax differences (Chen et al., 2010). We incorporate several independent variables in our study. In order to verify whether family firms are more or less tax aggressive than non family firms, we incorporate the ownership percentage in hands of the family ('Familyown') or alternatively, a dummy variable ('Familydummy') with a value ' 1 ' if more than $50 \%$ of the shares are owned by the family; ' 0 ' otherwise. Within the group of private family firms, we include 'Ceoown' which measures the percentage ownership by the CEO. We also include board effectiveness by studying CEO duality and the presence of outside board members. Governance literature generally suggests that as boards become increasingly independent of management, their monitoring effectiveness increases, thereby decreasing managerial opportunism (Harford et al., 2008). CEO duality ('Ceo_dual') 
has a value ' 1 ' if the firm's CEO is also the chair of the board of directors; ' 0 ' otherwise. Alternatively, we include 'ext' which has a value ' 1 ' if the board contains at least one outside board member; ' 0 ' otherwise. In each of the regressions we perform, we control for firm characteristics reported in prior literature (Chen et al., 2010; Frank et al., 2009) that are correlated with tax aggressive behavior. Therefore, we can ensure that our results are not driven by fundamental differences between family and non family firms and within the group of family firms. In our study, we control for the firm's profitability by incorporating the return on assets ('roa') and the firms leverage measured by long term debt divided by lagged assets ('lev'). A second set of control variables is related to the differences in book and tax reporting that can affect the tax aggressiveness measure. We include the firm's plant, property and equipment divided by lagged assets ('ppe') and the firm's intangible assets divided by lagged assets ('intang'). Lastly, we also control for firm size by including the natural logarithm of total assets of the previous year ('size'). In addition, for all regressions, we include dummies to control for year and industry fixed effects. Table 1 and table 2 present the descriptive statistics and correlation matrix for the main variables of our analysis.

Table 1: Descriptives and correlation matrix

\begin{tabular}{|c|c|c|c|c|c|c|c|c|c|c|c|}
\hline & Mean & Std. & & & & & & & & & \\
\hline & & dev. & 1 & 2 & 3 & 4 & 5 & 6 & 7 & 8 & 9 \\
\hline 1.ETR & 0.23 & 0.13 & 1 & & & & & & & & \\
\hline 2. Ceoown & 0.49 & 0.33 & $0.05^{*}$ & 1 & & & & & & & \\
\hline 3.Size & 315 & 3.20 & 0.02 & $-0.22^{m * *}$ & 1 & & & & & & \\
\hline 4. Roa & 0.20 & 0.21 & $-0.25^{\mathrm{mx}}$ & $0.06^{*}$ & $-0.17^{n \times x}$ & 1 & & & & & \\
\hline 5. Lev & 0.21 & 0.34 & $-0.16^{m \times m}$ & -0.03 & -0.05 & $-0.22^{m * x}$. & 1 & & & & \\
\hline 6. Ppe & 0.36 & 0.38 & $-0.13^{\mathrm{mx}}$ & -0.03 & -0.03 & -0.03 & $0.60^{\mathrm{n} *}$ & 1 & & & \\
\hline 7. Intang & 0.01 & 0.04 & $-0.05^{*}$ & -0.04 & -0.01 & 0.01 & $0.05^{\circ}$ & -0.02 & 1 & & \\
\hline $\begin{array}{l}8 . \\
\text { Ceo_dual }\end{array}$ & 0.53 & 0.49 & $0.07^{* *}$ & $0.35^{\mathrm{x} \times}$ & $-0.15^{\mathrm{nw}}$ & 0.04 & 0.03 & $0.06^{*}$ & -0.03 & 1 & \\
\hline 9. Ext & 0.81 & 0.39 & -0.01 & -0.01 & 0.02 & $-0.07^{* *}$ & -0.02 & $-0.10^{\mathrm{xx}}$ & $-0.08^{* *}$ & -0.05 & 1 \\
\hline
\end{tabular}

Table 1 reveals that the private family firms in our sample have an average asset size of 315,000 euros and have an average effective tax rate (ETR) of $23 \%$. On average, the CEO owns $50 \%$ of the shares. The firms are characterized by a rather high ROA of $20 \%$. Moreover, in more than $50 \%$ of the firms, the CEO is also the chair of the Board of Directors. In the majority of family firms (81\%), an outside director is serving on the board. Additionally, we add that in the total sample of family and non family firms, $57 \%$ of the firms are family firms. $41.81 \%$ of the firms are firms where no family is involved i.e. where the family has $0 \%$ of the shares. In $5.29 \%$ of the firms, the family owns a certain amount of shares but less than $50 \%$.

\section{Results}

In table 2 and table 3 , the results are presented. All regression models are estimated with OLS and robust standard errors are calculated. 
Table 2: Robust OLS regression on SMEs' tax aggressiveness

\begin{tabular}{|c|c|c|}
\hline Dep. variable: ETR & $(1)$ & (2) \\
\hline Familydummy & $0.0141^{\prime \prime \prime}(0.007)$ & \\
\hline Familyown & & $0.0134^{*}(0.007)$ \\
\hline Roa & $01134^{\pi \times \pi}(0.033)$ & $0.1136^{x \times \times}(0.033)$ \\
\hline Lev & $-0.0078(0.009)$ & $-0.0079(0.009)$ \\
\hline Ppe & $-0.0265^{x \times 1}(0.011)$ & $-0.0268^{\pi \times 1}(0.011)$ \\
\hline Intang & $-0.0873(0.076)$ & $-0.0877(0.076)$ \\
\hline Size & $0.0139^{x \times x}(0.003)$ & $0.0139^{x \times x}(0.003)$ \\
\hline Constant & $0.1257^{n \times x}(0.023)$ & $0.1274^{\pi \times \pi}(0.023)$ \\
\hline$R^{2}$ & 0.1057 & 0.1052 \\
\hline$F$ value & $8.69^{\times x \times}$ & $8.43^{x \times \pi}$ \\
\hline Number of obs. & 1650 & 1650 \\
\hline
\end{tabular}

Table 2 reveals that hypothesis 1 can be confirmed. Private family firms appear to be less tax aggressive compared to non family firms. The variable 'Familydummy' as well as 'Family own' reveals a significant positive effect. The other significant control variables have the expected sign. More profitable ('Roa') and larger firms ('size') seem to have a larger ETR whereas firms with more plant, property and equipment ('ppe') have a lower ETR. However, as argued above, private family firms are a heterogeneous group. Therefore, further analysis within the group of private family firms is provided in table 3.

Table 3: Robust OLS regression on family firms' tax aggressiveness

\begin{tabular}{|c|c|c|c|c|}
\hline $\begin{array}{c}\text { Dep. variable: } \\
\text { ETR }\end{array}$ & (1) & (2) & (3) & (4) \\
\hline Ceoown & $0.021(0.013)$ & $-0.152 \times(0.066)$ & $0.132 \quad(0.031)$ & $0.0029(0.025)$ \\
\hline Ceoown x Size & & $0.030^{\approx \times x}(0.011)$ & & \\
\hline Ext & & & $0.061^{x \times x}(0.019)$ & \\
\hline Ceoown x Ext & & & $-0.134^{\times \times x}(0.034)$ & \\
\hline Ceo_dual & & & & $0.0131(0.016)$ \\
\hline Ceoōwn $x$ & & & & $0.0128(0.030)$ \\
\hline Ceo_dual & & & & \\
\hline Roa & $0.171^{* \pi}(0.025)$ & $0.169^{* x *}(0.024)$ & $0.166^{* \pi x}(0.025)$ & $0.170^{\star \star x}(0.025)$ \\
\hline Lev & $-0.008(0.045)$ & $-0.007(0.046)$ & $-0.002(0.044)$ & $-0.008(0.045)$ \\
\hline Ppe & $-0.042(0.031)$ & $-0.041(0.031)$ & $-0.045(0.030)$ & $-0.042(0.031)$ \\
\hline Intang & $-0.156(0.130)$ & $-0.156(0.131)$ & $-0.169(0.128)$ & $-0.155(0.132)$ \\
\hline Size & $0.012^{\pi x x}(0.004)$ & $0.001(0.006)$ & $0.012^{x \times x}(0.004)$ & $0.013^{\times x \times}(0.004)$ \\
\hline Constant & $0.153^{\pi \times \star}(0.034)$ & $0.218^{x \times x}(0.042)$ & $0.106^{\times \approx \pi}(0.037)$ & $0.147^{\star \star \star}(0.036)$ \\
\hline$R^{2}$ & 0.122 & 0.129 & 0.136 & 0.126 \\
\hline$F$ value & $8.48^{x \times x}$ & $8.77^{x \times \pi}$ & $8.52^{x \times x}$ & $8.01^{x \times x}$ \\
\hline Number of obs. & 898 & 898 & 898 & 898 \\
\hline $\begin{array}{l}\text { ', significan } \\
\text { asymptotic stand } \\
\text { We also included }\end{array}$ & the $10 \%, 5 \%$ & id $1 \%$ level re & ctively (two-tai & d test). Robust \\
\hline
\end{tabular}


Regression (1) in table 3 does not seem to confirm hypothesis 2, with respect to the effect of the CEO ownership share on tax aggressive behavior. Regression (1) shows no significant effect of 'Ceoown'. However, we argued that firm size may be an important moderator in the context of tax aggressive behaviour. Very small, young private family firms may not have the experience to engage in tax aggressive behavior and are fully occupied with the core business and/or survival of the firm. Therefore, we included in regression (3) the moderating effect of firm size ('size') on the relationship between 'Ceoown' and 'ETR'. We included the term 'Ceoown $x$ size'. From the results in table 3, we cannot see in regression (2) what the impact is of the ownership share of the CEO on tax aggressive behavior when firm size increases. In order to capture the total effect, we have to take into account the coefficient of 'Ceoown' as well as the interaction term and the value of the moderating variable which is 'Size' (Kam and Franzese, 2007). Figure 1 graphically presents the marginal effect of the ownership share of the CEO on 'ETR' as firm size changes.

\section{Marginal Effect of 'Ceoown' on tax aggressive behavior}

Dependent Variable: ETR

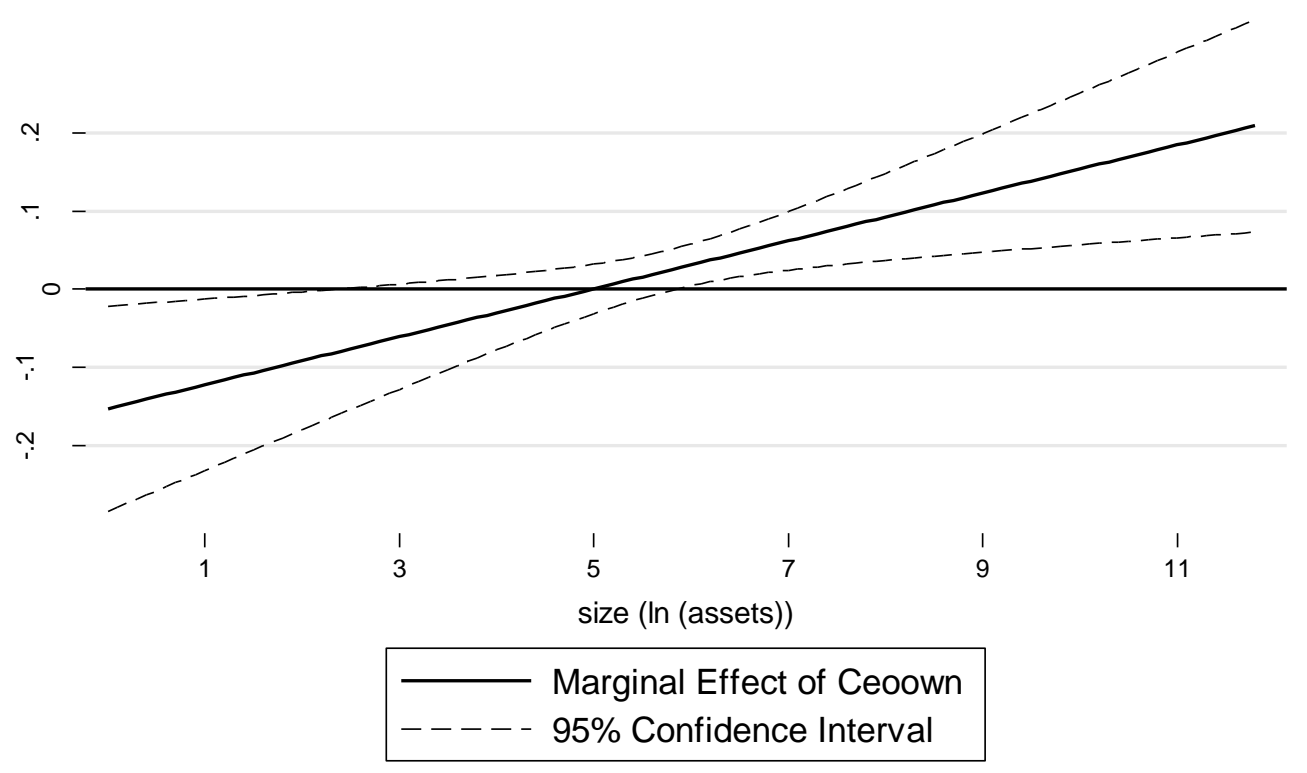

Figure 1: Marginal effect of 'Ceoown' on tax aggressive behavior (ETR)

Any point of this line is $\partial \mathrm{ETR} / \partial$ Ceoown $=\beta_{1}+\beta_{3}($ Size $)$. The dotted lines represent the $95 \%$ confidence interval, which allows us to determine the conditions under which the ownership share of the CEO has a significant impact on the firm's 'ETR'. Figure 1 shows that the ownership share of the CEO has a significant positive effect on ETR, indicating a lower extent of tax aggressiveness if the family firm has more than 400,000 euro of assets. The positive effect increases as firm size increases. This confirms our hypothesis 2 indicating that as the ownership share of the CEO increases, the family firm becomes less tax aggressive. For the smaller family firms in our database, we find no significant effect of 'Ceoown' on the tax aggressive behavior.

With respect to hypothesis 3, the variable 'Ext' is included in regression (3) as well as the interaction term 'Ceoown x Ext'. The interaction term has the predicted negative sign and is significant at $1 \%$ level. The CEO ownership share no longer affects the tax aggressive behavior of the firm if the board includes an independent outside director. The benefit for CEO's to engage in tax aggressive behaviour, at the expense of other shareholders, is nearly absent when the firm hires an external board member due to a 
higher monitoring effectiveness thereby limiting possible rent extraction behavior. This confirms hypothesis 3. Regression (4) extends this discussion and takes into account the moderating effect of CEO duality ('CEO_dual'). Therefore, we include in regression (4), Ceo_dual and the interaction term 'Ceoown x Ceo_dual'. Contrary to what we expected, CEO duality appears to have no significant moderating effect. It seems that if the board is chaired by the CEO, the board does not play a mitigating (monitoring) role in reducing rent extraction behavior by the CEO and thus reducing the motivation for tax aggressive behavior.

\section{Conclusion}

In this paper, we examine the tax aggressiveness of private family firms, relative to their non-family counterparts. We find that private family firms appear to be less tax aggressive than private non family firms which is in line with Chen et al. (2010) based on public family firms. This result highlights the importance of the non financial costs related to tax aggressive behavior being the possible reputation damage and loss of socioemotional wealth as indicated by Gomez-Mejia et al. (2007). Even though tax aggressive behaviour provides tax savings and allows the CEO to mask rent extraction to the detriment of other shareholders, the non financial costs seem to outweigh the benefits. Within the group of private family firms, our paper contributes to a better understanding of the impact of the ownership structure on private family firms' tax reporting. Results show that firms with a higher CEO ownership stake are less eager to engage in tax aggressive behaviour, while CEOs with a lower ownership share are more eager to engage in tax aggressive behaviour. This result highlights the importance of the unique agency conflict between the CEO (agent and possibly principal) and (other) shareholders (principals) in determining family firms' tax aggressive behavior. Finally, results show that the presence of an outside director in the board improves the monitoring effectiveness thereby limiting possible rent extraction behavior by the CEO. Therefore, these boards appear to reduce the tax aggressive behavior of private family firms where the CEO owns a low ownership share.

\section{Literature}

Ang, J.S., Cole, R.A. and Lin, J.W. (2000) "Agency costs and ownership structure", Journal of Finance, Vol. 55, No. 1, pp 81-106.

Banghoj, J., Gabrielsen, G., Petersen, C., Plenborg, T. (2010) "Determinants of executive compensation in privately held firms", Accounting and Finance, forthcoming.

Beatty, A. and Harris, D. (1999) "The effects of taxes, agency costs and information asymmetry on earnings management: a comparison of public and private firms", Review of Accounting Studies, Vol. 4, pp 299-326.

Blumentritt, T., Keyt, A. and Astrachan, J. (2007) "Creating an environment for successful nonfamily CEOs: an exploratory study of good principals", Family Business Review, Vol. 20, No. 4, pp 321-335.

Chen, S., Chen, X., Cheng, Q. and Shevlin, T. (2010) "Are family firms more tax aggressive than nonfamily firms?", Journal of Financial Economics, Vol. 95, pp 41-61.

Chua, J.H., Chrisman, J.J. and Sharma, P. (2003) "Succession and nonsuccession concerns of family firms and agency relationship with nonfamily managers", Family Business Review, Vol. 16, No. 2, pp 89107.

Chua, J., Chrisman, J. and Sharma, P. (1999) "Defining the family business by behavior", Entrepreneurship: Theory and Practice, Vol. 23, pp 19-39.

Desai, M. and Dharmapala, D. (2006) "Corporate tax avoidance and high-powered incentives", Journal of Financial Economics, Vol. 84, pp 591-623.

Dyreng, S., Hanlon, M., and Maydew, E. (2010) "The effects of executives on corporate tax avoidance", The Accounting Review, Vol. 85, No. 4, pp 1163-1189.

Fama, E.F., and Jensen, M.C. (1983) "Separation of ownership and control", Journal of Law and Economics, Vol. 26, pp 301-325.

Frank, M., Lynch, L., and Rego, S. (2009) "Tax reporting aggressiveness and its relation to aggressive financial reporting", The Accounting Review, Vol. 84, pp 467-496. 
Gedajlovic, E., and Carney, M. (2010) "Market, hierarchies and families: toward a transaction cost theory of the family firm", Entrepreneurship, Theory and Practice, Vol. 34, pp 1145-1171.

Gersick, K., Davis, J., Hampton, M. and Lansberg, I. (1997) Generation to generation: life cycles of the family business, Harvard Business School Press: Boston MA.

Gomez-Mejia, L., Haynes, K, Nunez-Nickel, M., Jacobson, K. and Moyano-Fuentes, J. (2007) "Socioemotional wealth and business risks in family-controlled firms: evidence from Spanish olive mills", Administrative Science Quarterly, Vol. 52, pp 106-137.

Harford, J., Mansi, S. and Maxwell, W. (2008) "Corporate governance and firm cash holdings in the US", Journal of Financial Economics, Vol. 87, pp 535-555.

Jensen, M., and Meckling, W. (1976) "Theory of the firm: managerial behavior, agency costs and ownership structure", Journal of Financial Economics, Vol. 3, pp 305-360.

Johannisson, B. and Huse, M. (2000) "Recruiting outside board members in the small family business: an ideological challenge", Entrepreneurship \& Regional Development, Vol. 12, pp 353-378.

Kam, C., and Franzese, R. (2007) Modeling and interpreting interactive hypotheses in regression analysis, University of Michigan Press.

Karra, N., Tracey, P. and Phillips, N. (2006) "Altruism and agency in the family firm: exploring the role of family, kinship, and ethnicity”, Entrepreneurship: Theory \& Practice, November, pp 861-877.

Lubatkin, M., Schulze, W., Ling, Y. and Dino, R. (2005) "The effects of parental altruism on the governance of family-managed firms", Journal of Organizational Behavior, Vol. 26, pp 313-330.

Mills, L., and Newberry, K. (2001) "The influence of tax and non-tax costs on book-tax reporting differences: public and private firms", Journal of American Tax Association, Vol. 23, pp 1-19.

Schulze, W.S., Lubatkin, M., Dino, R. and Buchholtz, A. (2001). "Agency relationships in family firms: theory and evidence", Organization Science, Vol. 12, pp 99-116.

Schulze, W.S., Lubatkin, M. and Dino, R. (2003) "Toward a theory of agency and altruism in family firms", Journal of Business Venturing, Vol. 18, No. 4, pp 473-490.

Tsai,W., Hung, J., Kuo,Y. and Kuo, L. (2006) "CEO tenure in Taiwanese family and nonfamily firms: an agency theory perspective", Family Business Review, Vol. 19, No. 1, pp 11-28.

Voordeckers, W., Van Gils, A. and Van den Heuvel, J. (2007) "Board composition in small and mediumsized family firms", Journal of Small Business Management, Vol. 45, No. 1, pp 137-156.

Westhead, P., and Howorth, C. (2007) "Types' of private family firms: An exploratory conceptual and empirical analysis", Entrepreneurship \& Regional Development, Vol. 19, pp 405-431. 
